\title{
Payment in challenge studies from an economics perspective
}

\author{
Sandro Ambuehl (1), ${ }^{1}$ Axel Ockenfels 이, ${ }^{2}$ Alvin E. Roth (1) ${ }^{3}$
}

We largely agree with Grimwade et al's ${ }^{1}$ conclusion that challenge trial participants may ethically be paid, including for risk. Here, we add further arguments, clarify some points from the perspective of economics and indicate areas where (behavioural) economists can support the development of a framework for ethically justifiable payment. Our arguments apply to carefully constructed and monitored controlled human infection model (CHIM) trials that have been appropriately reviewed and approved.

Participants in medical studies perform a service. Outside the domain of research participation, there is nearly universal agreement that workers providing a service should be compensated fairly, and that work involving more discomfort and risk should be compensated more generously. Accordingly, labour regulations impose floors (minimum wage laws), not caps on compensation. Caps, even if intended to protect against undue inducement, also raise concerns about illegal price-fixing that disadvantages workers. Such limits on payment for egg donors have successfully been challenged in court. ${ }^{\mathrm{i}}$

Moreover, caps on compensation may harm everyone at risk of infection, not just potential participants. Insufficient compensation may impede the recruitment of enough suitable subjects, for example, when representativeness of the subject sample is required. Delays in vaccine development not only prolong disruption of social, educational and economic activity but also lead to excess infections and deaths. Unlike paid CHIM participants, individuals exposed to such infection do not accept it voluntarily, are

${ }^{i}$ Kamakahi v. American Society for Reproductive Medicine, U.S. District Court Northern District of California, Case 3:11-cv-01781-JCS, 2016.

'Department of Economics, University of Zurich, Zurich, Switzerland

2Department of Economics, University of Cologne, Köln, Germany

${ }^{3}$ Department of Economics, Stanford University, Stanford, California, USA

Correspondence to Dr Alvin E. Roth, Department of Economics, Stanford University, Stanford, CA 94305, USA; alroth@stanford.edu not compensated for it, and are unlikely to receive the level of medical supervision afforded to closely monitored CHIM participants.

Payment caps can lead to attempts to circumvent the regulation. For example, many countries that prevent payment for the donation of blood plasma instead import it from the USA where payment is legal-the volume of the US export market for plasma products approaches \$20 billion per year. ${ }^{\text {ii }}$ Similarly, restrictions on CHIM trial payments may lead to an increase in trials in countries with less stringent regulation.

In practice, designing markets and payment schemes requires attention to the details of implementation. Here, we note that increasing hourly pay by a riskcompensation percentage as proposed in the target article provides compensation proportional to risk only if the risk increases proportionally with the number of hours worked. (Some risky tasks take little time; imagine challenge trials to test bulletproof vests.) To ensure that equal consequences are compensated with equal amounts across a wide variety of studies, we instead recommend a three-part contract consisting of: (1) salary for time involvement that is adjusted to account for the amount of discomfort experienced during participation, (2) insurance against ex post adverse outcomes and (3) ex ante compensation for risks that cannot be compensated ex post (such as death). Such a scheme also increases transparency about what is requested from participants and thus contributes to high-quality participation decisions.

Ethical judgement of payment in CHIM trials is partially based on predictions about the effects on prospective participants' behaviour and about the quality of their decision making. These predictions can be tested empirically and interpreted through the lens of precise models of the underlying motivational and cognitive mechanisms. Ambuehl $^{2}$ for instance, employs controlled laboratory experiments to study whether participation incentives harm decision

iihttps://marketdesigner.blogspot.com/2020/05/ plasma-and-plasma-products-such-as.html. quality. While higher incentives make subjects more interested in learning about the upsides of the transaction and less interested in the downsides, such effects can arise from rational decision making; they do not necessarily indicate deficient reasoning. Indeed, direct measurements of subjects' welfare in that experiment indicate no negative effect of participation incentives across a wide variety of conditions. Accordingly, this study suggests that limits on payments are not justified if one takes subjects' own objectives as the relevant normative standard.

That said, even rational decisions may raise ethical concerns. In fact, attentional mechanisms imply that high payments tend to disproportionately entice those individuals who have more difficulty gathering information about the risks (Ambuehl et al. ${ }^{3}$ ). Absent informed consent requirements, these participants may be more likely to regret their decision ex post

Overall, the fact that payments can alter and possibly interfere with good decision making speaks to the need for robust informed consent, not against making appropriate payments. Indeed, survey respondents do not object to incentives per se, they object to participation that is based on an insufficient understanding of the personal consequences of participation (Ambuehl and Ockenfels ${ }^{4}$ ). Caps on payment may even impede well-informed decision making because study participants perceive the payment magnitude as a signal of risk (Cryder et $a l^{5}$ ). Low payments will lead such subjects to underestimate the risks, and may cause them to participate in trials they would rather avoid.

Finally, we applaud Grimwade et $a l^{1}$ for surveying both practitioners and members of the general population. We often know too little about how the views of professionals (both practitioners and advisors) compare with those of the populations with which they interact. Their finding that the general public does not share potential ethical concerns regarding payment of CHIM participants parallels the handful of existing surveys on the topic. ${ }^{6} 7$ Activities that depend on public participation require social support as well as ethical justification. Understanding the similarities and differences between professional and popular judgements can help both to assess the likelihood of success, and to highlight issues about which communication between professional and public audiences is particularly important.

There are many potential explanations for divergences of judgements between ethicists 
and the general public, ${ }^{8}$ including cognitive biases. For example, Ambuehl et al show that individuals tend to impose paternalistic restrictions on others as if they sought to align others' choices with their own aspirations (projective paternalism). The effect arises because individuals are insufficiently aware of differences between themselves and others (false consensus). It is important to be aware of such biases, especially among highly trained and privileged professionals who are dissimilar from the prospective study participants they hope to enlist, and whose decisions they seek to regulate. Indeed, in all areas where the question has been studied, experts such as financial advisors, CEOs, elected politicians and economists, as well as philosophers ${ }^{10}$ and physicians ${ }^{11}$ are as susceptible to cognitive biases as ordinary citizens.

The current discussion about payment in challenge trials is important because the potential benefits of well-designed challenge trials that could accelerate the development of safe and effective vaccines are enormous. Overall, economic research has shown, first, that ethical concerns over high payments may rely on intuitive predictions about behavioural effects that find little or no empirical support, and that the dangers of underpayment are at least as real as those of overpayment. Second, a part of the ethics literature attaches significantly more weight to concerns of undue inducement than the general population. Accordingly, it appears to us that there is sufficient public support for preparing for challenge trials, with paid participants, without a need for excessive ethical concern that payments might inadvertently become too generous to trial participants.
Acknowledgements We received helpful comments from Professors Emily Largent and Holly Fernandez Lynch.

Contributors All authors contributed equally to writing this commentary.

Funding $S A$ and $A O$ gratefully acknowledge funding from the European Research Council (ERC) under the European Union's Horizon 2020 research and innovation programme (grant agreement No 741409). AO gratefully acknowledges funding by the German Research Foundation (DFG) under Germany's Excellence Strategy (EXC 2126/1-390838866).

Competing interests None declared.

Patient consent for publication Not required.

Provenance and peer review Commissioned; internally peer reviewed.

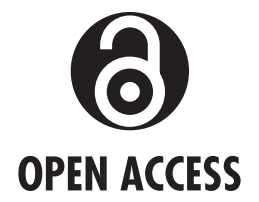

Open access This is an open access article distributed in accordance with the Creative Commons Attribution Non Commercial (CC BY-NC 4.0) license, which permits others to distribute, remix, adapt, build upon this work non-commercially, and license their derivative works on different terms, provided the original work is properly cited, appropriate credit is given, any changes made indicated, and the use is non-commercial. See: http://creativecommons.org/ licenses/by-nc/4.0/.

(C) Author(s) (or their employer(s)) 2020. Re-use permitted under CC BY-NC. No commercial re-use. See rights and permissions. Published by BMJ.

(D) Check for updates

To cite Ambuehl S, Ockenfels A, Roth AE. J Med Ethics 2020;46:831-832.

Received 28 September 2020

Accepted 29 September 2020

Published Online First 28 October 2020

\section{SLinked}

- http://dx.doi.org/10.1136/medethics-2020-106438 - http://dx.doi.org/10.1136/medethics-2020-107060

$J$ Med Ethics 2020:46:831-832.

doi:10.1136/medethics-2020-106891

ORCID iDs

Sandro Ambuehl http://orcid.org/0000-0001-95002698

Axel Ockenfels http://orcid.org/0000-0003-14560191

Alvin E. Roth http://orcid.org/0000-0002-8834-6481

\section{REFERENCES}

1 Grimwade 0, Savulescu J, Giubilini A, et al. Payment in challenge studies: ethics, attitudes and a new payment for risk model. J Med Ethics 2020:;46:815-26.

2 Ambuehl Set al. An offer you can't refuse? CESifo Working Paper 2017;6296.

3 Ambuehl S, Stewart C, Ockenfels A, et al. CESifo working paper 2020;7091.

4 Ambuehl S, Ockenfels $A$. The ethics of incentivizing the uninformed: a vignette study. Am Econ Rev 2017;107(5):91-5.

5 Cryder CE, John London A, Volpp KG, et al. Informative inducement: study payment as a signal of risk. Soc Sci Med 2010;70(3):455-64.

6 Ambuehl S, Niederle M, Roth AE. More money, more problems? Can high pay be coercive and repugnant? Am Econ Rev 2015;105(5):357-60.

7 Roth AE, Wang SW. Popular repugnance contrasts with legal bans on controversial markets. Proc Natl Acad SCi USA 2020;117(33):19792-8.

8 Roth AE. Repugnance as a constraint on markets. Econ Perspec 2007;21(3):37-58.

9 Ambuehl S, Bernheim BD, Ockenfels A. What Motivates paternalism? An experimental study. Conditionally accepted at the American Economic Review 2020.

10 Schwitzgebel E, Cushman F. Philosophers' biased judgments persist despite training, expertise and reflection. Cognition 2015;141:127-37.

11 Redelmeier DA, Koehler DJ, Liberman V, et al. Probability judgement in medicine: discounting unspecified possibilities. Med Decis Making 1995; 15(3):227-30. 